FORMULASI PERLINDUNGAN HUKUM PENYANDANG DISABILITAS DALAM SISTEM PEREKRUTAN PNS DALAM PERSPEKTIF HAK ASASI MANUSIA

\author{
FORMULATION OF LEGAL PROTECTION FOR PERSONS WITH DISABILITIES \\ IN THE CIVIL SERVICE RECRUITMENT SYSTEM IN THE PERSPECTIVE OF \\ HUMAN RIGHTS
}

\title{
Sukamto Satoto*, Hartati, Nazifah
}

Faculty of Law, Universitas Jambi

Jalan Raya Jambi Muara Bulian KM. 15 Mendalo Indah, 36361, Indonesia

\section{INFO ARTIKEL}

\section{Riwayat Artikel:}

Diterima : 11 Oktober 2021

Disetujui : 26 Desember 2021

\section{Keywords:}

formulation, disability, human right.

\section{Kata Kunci:}

formulasi, disabilitas,

hak asasi manusia.

\section{*) Korespondensi:}

E-mail: sukamtosatoto@yahoo.co.id
Abstract: this research aimed to fulfill the rights of persons with disabilities to get jobs according to their fields without reducing their rights. One of them was the recruitment of civil servant candidates. The research method used was normative juridical with literature study. Decent work is a right for every human being without exception. Various racial, ethnic, and religious backgrounds that are part of human identity do not prevent him from getting his rights, likewise with the physical or non-physical conditions that underlie a human being. Every human being who has a certain physical or nonphysical background also has the same right to get a decent job, including people with disabilities. The State of Indonesia has ratified the Convention on the Rights of Persons with Disabilities into Law Number 19 of 2011. In the preamble to the law, it is explained that countries that sign the Convention should promote and protect the rights and dignity of persons with disabilities and increase the participation of persons with disabilities in the civil, political fields, economic, social, and cultural-based on an equal opportunity. It means that the Indonesian government is legally obliged to fulfill the rights of persons with disabilities, especially regarding the right to work in Indonesia.

Abstrak: tujuan dari penelitian ini adalah memenuhi hak penyandang disabilitas untuk mendapatkan pekerjaan sesuai dengan bidangnya tanpa mengurangi haknya. Salah satunya adalah rekrutmen calon pegawai negeri sipil. Metode penelitian yang digunakan adalah yuridis normatif dengan studi kepustakaan. Pekerjaan yang layak merupakan hak bagi setiap manusia tanpa terkecuali. Berbagai latar belakang ras, suku, dan agama yang menjadi bagian dari identitas manusia tidak menjadi penghalang bagi setiap manusia untuk mendapatkan haknya. Begitu juga dengan kondisi fisik atau non fisik yang mendasari seorang manusia. Setiap manusia yang memiliki latar belakang fisik atau non fisik tertentu juga memiliki hak yang sama untuk mendapatkan pekerjaan yang layak, termasuk penyandang disabilitas. Negara Indonesia telah meratifikasi Konvensi Hak Penyandang Disabilitas menjadi Undang-Undang Nomor 19 Tahun 2011. Dalam pembukaan undang-undang tersebut dijelaskan bahwa negara-negara yang menandatangani konvensi memiliki kewajiban untuk memajukan dan melindungi hak dan martabat penyandang disabilitas dan meningkatkan 
partisipasi mereka di bidang sipil, politik, ekonomi, sosial, dan budaya berdasarkan persamaan kesempatan, artinya pemerintah Indonesia secara hukum berkewajiban memenuhi hak-hak penyandang disabilitas, khususnya mengenai hak untuk bekerja di Indonesia.

\section{INTRODUCTION}

Indonesia is a country based on law or referred to as a state of law, this is stated in the 1945 Constitution of the Republic of Indonesia, one of the characteristics of a state of law is the protection of human rights. The goals of a country are generally the same, namely the welfare of the people's lives even though they have different forms and systems of government. The obligation of the government in every country is to give equal rights and obligations to every citizen in the context of realizing the ideals of the country, including persons with disabilities.

The regulation regarding persons with disabilities was first regulated in Law Number 4 of 1997 concerning Persons with Disabilities but this arrangement does not have a human rights perspective. The content of Law Number 4 of 1997 concerning persons with disabilities is more compassionate (charity based) and the fulfillment of the rights of persons with disabilities is still considered a social problem whose policies for fulfilling their rights are only social security, social rehabilitation, social assistance, and social welfare improvement. Persons with disabilities should have the same opportunities in an effort to develop themselves through independence as human beings with dignity.

The enactment of Law Number 19 of 2011 concerning the Ratification of the Convention on the Rights of Persons with Disabilities on November 10, 2011, it shows the commitment and seriousness of the Government of Indonesia to respect, protect and fulfill the rights of persons with disabilities which is ultimately expected can improve the welfare of persons with disabilities. Thus, persons with disabilities have the right to be free from torture or cruel, inhuman, degrading treatment, free from exploitation, violence and arbitrary treatment, and have the right to have respect for their mental and physical integrity on an equal basis with others, including it includes the right to obtain protection in the field of manpower in the context of independence (Gostin \& Gable, 2004).
Persons with disabilities have the same rights and obligations as society in general, so it is appropriate that in the context of implementing good governance (Gostin \& Mann, 1994). Persons with disabilities are also entitled to decent work opportunities, one of which is the opportunity to become part of civil servants, which is marked by the issuance of a Ministerial Regulation. Empowerment of State Apparatus and Bureaucratic Reform of the Republic of Indonesia Number 23 of 2019 which in the recruitment of Civil Servant Candidates in 2019 prepares general and special formations for persons with disabilities.

The existence of civil servant candidate recruitment for persons with disabilities is a form of realization that every citizen has the right to have equal opportunities in government. Everyone has the right to have equal opportunities in government. The aim is to implement the principle of equality, including for persons with disabilities who will register as civil servant candidates. Provisions and requirements for special civil servant candidate recruitment for persons with disabilities are stated in letter $\mathrm{F}$ number 3 Regulation of the Minister of State Apparatus Empowerment and Bureaucratic Reform of the Republic of Indonesia Number 23 of 2019 concerning Criteria for Determining the Needs of Civil Servants and Implementation of Selection of Candidates for Civil Servants in 2019.

Even though there are already formations for disability, discrimination still occurs in disability formations, which has not provided equal space and justice for all types of disabilities. There are a number of requirements for applicants with disabilities in certain institutions where the criteria for disabilities that can apply are being able to see, hear and speak well, then also be able to move using a walking aid other than a wheelchair.

Using these discriminatory conditions will clearly close the opportunity for the blind, deaf, speech impaired and physically disabled 
to participate in the selection of civil servant candidate admissions. Article 45 of Law Number 8 of 2016 concerning Persons with Disabilities, which stipulates that the Government and Regional Governments are required to guarantee a fair and non-discriminatory process of recruitment, acceptance, job training, job placement, work continuity, and career development and without discrimination to persons with disabilities. discrimination, all persons with disabilities have equal opportunities, what will determine later is the competence and capability of each during the selection process.

This recruitment stage is a very important stage of the selection and placement mechanism for civil servant candidates. If the recruitment system is not good, it is feared that equality of opportunity for persons with disabilities in the government will not be realized (Stein \& Lord, 2010). Therefore, it is necessary to formulate legal protection for persons with disabilities in the civil servant candidate recruitment system which is viewed from the perspective of human rights. The purpose of this study is to understand and analyze the formulation of legal protection for persons with disabilities in the recruitment system for prospective civil servants' candidates in the perspective of human rights.

\section{METHODS}

This research is normative legal research, research on legal principles and legal systematics, namely research that is focused on examining the application of rules or norms in positive law (Ibrahim, 2005). The type of research used by the author is normative juridical research by examining all legal materials related to the formulation of legal protection for persons with disabilities in the civil servant candidate recruitment system in the perspective of human rights. The research approach used in this research is the statutory approach, the conceptual approach and the case approach. The legislative approach was chosen because what will be studied are various legal regulations that are the focus as well as the central theme to be able to explore all policies owned by the government in providing legal protection for persons with disabilities in the recruitment system for prospective civil servants from a human rights perspective. A conceptual approach is used to understand legal concepts related to legal protection for persons with disabilities, then a case approach is used to look at cases of persons with disabilities in the recruitment system for prospective civil servants as input for legal explanations. The method of collecting legal materials is carried out using a computerized system consisting of legal materials, secondary legal materials, and tertiary legal materials.

\section{RESULTS AND DISCUSSION}

Legal Protection for Persons with Disabilities

Persons with Disabilities according to the Big Indonesian Dictionary, persons with disabilities are defined as people who have (suffered) something. While disability is an Indonesian word that comes from the English loan word disability (plural: disabilities) which means disability or disability. Persons with Disabilities according to Law Number 19 of 2011 concerning Ratification of the Convention on The Right Of Person With Disabilities are people who have physical, mental, intellectual, or sensory limitations in the long term who interact with the environment and attitudes of the community can encounter obstacles that make it difficult to participate fully and effectively on the basis of equal rights (UN, 2014). Constitutionally they (persons with disabilities) have the same right to be able to live in prosperity by getting a job and working properly. As stated in Article 28A of the 1945 Constitution that everyone has the right to live and has the right to defend his life and life. Then the right to get decent work is specifically regulated in Article 27 Paragraph (2) that every citizen has the right to work and a decent living for humanity. In addition, there is also Article 28D Paragraph (2) of the 1945 Constitution which has mandated that basically everyone has the right to work and receive fair and proper remuneration and treatment in the employment relationship. The fulfillment of these rights certainly cannot be separated from the obligations of the regional government as one of the holders of power. Local governments have the power to make regulations/policies as representatives of local governments to realize and protect these rights. The obligation of local governments is stated in Article 28I that the protection, promotion, enforcement and fulfillment of human rights are the responsibility of the state, especially local governments. 
The basic idea of the Indonesian legal state cannot be separated from the basic idea of rechtsstaat XVIII laid the basis for legal protection for the people on the principle of legality, namely that all laws must be "positive" (Hadjon, 1996). That means that the law must be formed consciously, he further argues, that the idea of rechtsstaat places the position of wetgever to be important because the positive law that is formed is expected to guarantee legal protection for the people, including through the distribution of power (Hadjon, 1996).

In a modern rechtsstaat (as correctly translated by the 1945 Constitution as a state based on law), the function of legislation is not only to give form to the values and norms that apply and live. in society, and the law is not just a product of the state's function in the field of regulation (Latief, 2005). Law has the aim of realizing order in society and legal certainty, but there is a much more important goal that is the goal of law, namely justice. There is a deeper and more essential purpose of the law, namely that the law leads to justice. Laws that do not lead to justice are not laws. Laws that are voided in terms of justice, embody a tool of force, a tool of power rather than a dictatorial government. Therefore, those of us who are called to shepherd the law, need to remain vigilant so that the law we shepherd leads to justice and carries out justice (Notohamidjojo, 1975). The ultimate goal of law is justice, which must be achieved through a legal and independent institution within a country. This shows the importance of realizing justice for every citizen (human) as a legal orientation.

Increasing discrimination against groups of persons with disabilities, the state is then made aware of the importance of recognizing that "Persons with disabilities are human beings who are equal to other human beings, equal in rights and free to make choices, therefore there are special rights for groups of persons with disabilities" (Fadhli, 2014). Differential treatment of disability is a form of discrimination (Awaliyah, 2016). Special rights are not special rights, but these rights are given so that persons with disabilities are able to maintain their identity, characteristics and distinctive traditions. Special rights as well as non-discriminatory treatment are equally important to achieve equal treatment. Therefore, the principles of equality and non- discrimination are very important in human rights (Soeprapto et al., 2012).

The 1945 Constitution of the Republic of Indonesia (UUD 1945) as the highest basic law in the life of the nation and state in Indonesia, regulates various constitutional rights of citizens, such as the right to get a job and a decent life as stated in Article 27 paragraph (2) Article 31 of the 1945 Constitution, as well as the right to education. The 1945 Constitution includes a series of provisions that guarantee human rights. These provisions expressly regulate the State's obligations on human rights. Article 28 I paragraph (4) of the 1945 Constitution states that "The protection, promotion, enforcement and fulfillment of human rights is the responsibility of the State, especially the government". It is further stated that "To uphold and protect human rights in accordance with the principles of a democratic rule of law, the implementation of human rights is guaranteed, regulated and set forth in laws and regulations". In which persons with disabilities are one of the things that require equalization or equality with other communities.

Persons with disabilities according to Law Number 8 of 2016 concerning persons with disabilities law are any person who has physical, intellectual, mental and/or sensory limitations in the long term who in interacting with the environment can take obstacles and difficulties to participate fully and effectively with other citizens based on equal rights (Maftuhin, 2016). Persons with disabilities law the term used is persons with disabilities who have equal rights in the eyes of the law without distinguishing a person's physical form or background.

In addition, persons with disabilities have the same rights and obligations as society in general, so that in the context of good governance, persons with disabilities are entitled to decent work opportunities (Lawson, 2006). One of the government policies is to provide job opportunities for persons with disabilities to become part of the Civil Servant, which is marked by the Regulation of the Minister of Administrative Reform and Bureaucratic Reform of the Republic of Indonesia Number 36 of 2018 that provides job opportunities for the recruitment of Candidates for Civil Servants. in 2018 by preparing special formations for people with disabilities. The recruitment of 
civil servants for persons with disabilities is a form of recognition of freedom and equality of rights which are basic rights in a state of law, especially the recognition of freedom in state life and government activities.

In Article 65 paragraph (1) letter b of the State Civil Apparatus Law it is explained that the requirements to become a civil servant are physically and mentally healthy, but in the explanation of the article it is explained that the physical health requirements for persons with disabilities are adjusted to the needs of carrying out the work. To support persons with disabilities to become civil servants through the civil servant candidate test, persons with disabilities must also get decent jobs when they become civil servants. Decent work here when viewed according to the explanation of Article 65 paragraph (1) letter b of the State Civil Apparatus Law is the need for carrying out work that is adjusted to the degree of disability possessed by the person with disability. In the explanation of Article 65 paragraph (1) letter b of the State Civil Apparatus Law, it is explained that the requirements for physical health for persons with disabilities are adjusted to the needs of carrying out work. So, when people with disabilities have passed the civil servant candidate selection and are then appointed as civil servants, their work will be adjusted to the degree of disability they have.

Law Number 39 of 1999 concerning Human Rights provides legal certainty for the protection of human rights for everyone. Persons with disabilities are human beings, so the human rights of persons with disabilities must be protected and their needs met. Based on the Law of the Republic of Indonesia Number 39 of 1999 concerning Human Rights in chapter I, General Provisions Article 1, human rights are a set of rights that are inherent in the nature of human existence as creatures of God almighty and are his grace that must be respected, upheld and protected by state, law, government and everyone for the sake of honor and protection of human dignity. Respect and dignity for human rights is a noble thing. The existence of mutual respect, tolerance among fellow creatures of God Almighty, can always provide a sense of peace for anyone in this world.

The fulfillment and protection of the rights of persons with disabilities are all actions and/or activities to guarantee and protect the constitutional rights of persons with disabilities in accordance with human dignity and to avoid acts of violence and discrimination. The objectives of protecting and fulfilling the rights of persons with disabilities include: increasing the level of welfare, quality and survival and independence of persons with disabilities; (a) improve the social and economic resilience of persons with disabilities; (b) increasing the capacity, concern and responsibility of the Provincial Government, the business world and the community in protecting and fulfilling the rights of persons with disabilities in an institutional and sustainable manner; and (c) improve the quality of life and livelihoods of persons with disabilities.

\section{CONCLUSION}

The 1945 Constitution of the Republic of Indonesia, as the highest basic law in the life of the nation and state in Indonesia, regulates various constitutional rights of citizens, such as the right to get a job and decent life as stated in Article 27 paragraph (2) in 1945 constitution. Civil Servant candidate recruitment for persons with disabilities is a new policy. It provides opportunities for persons with disabilities to obtain the right to work in the field of government, central, regional agencies, state-owned enterprises, and regionally-owned enterprises provided that in the recruitment of civil servant candidates for persons with disabilities they have differences in accessibility and number of formation positions by considering the level of disability. The fulfillment and protection of the rights of persons with disabilities are all actions to guarantee and protect the constitutional rights of persons with disabilities under human dignity and to avoid acts of violence and discrimination.

\section{REFERENCES}

Awaliyah, S. (2016). The Effectiveness of AntiDiscrimination Laws for Job Seekers in Indonesia. Journal of Law, Policy and Globalization, 51(1), 41-48.

Fadhli, Y. Z. (2014). Kedudukan Kelompok Minoritas dalam Perspektif HAM dan Perlindungan Hukumnya di Indonesia. Jurnal Konstitusi, 11(2). 190-201.

Gostin, L. O., \& Gable, L. (2004). The Human Rights of Persons with Mental Disabilities: 
A Global Perspective on The Application of Human Rights Principles to Mental Health. Md. L. Rev., 63(1), 20-29.

Gostin, L., \& Mann, J. M. (1994). Towards the Development of a Human Rights Impact Assessment for The Formulation and Evaluation of Health policies. Health \& Hum. Rts., 1(1), 58-69.

Hadjon, P. M. (1996). Kedaulatan Rakyat, Negara Hukum dan Hak-hak Asasi Manusia. Kumpulan Tulisan dalam rangka 70 tahun Sri Soemantri Martosoewignjo. Media Pratama, Jakarta.

Ibrahim, J. (2005). Teori dan Metode Penelitian Hukum Normatif. Cetakan Pertama. Malang: Bayumedia Publishing.

Latief. A. (2005). Hukum dan Pengaturan Kebijaksanaan (Beleidsregel) Pada Pemerintah Daerah. Yogyakarta: UII Press.

Lawson, A. (2006). The United Nations Convention on the Rights of Persons with Disabilities: New Era or False Dawn. Syracuse J. Int'l L. \& Com., 34(2), 563.

Maftuhin,A. (2016). Mengikat Makna Diskriminasi: Penyandang Cacat, Difabel dan Penyandang Disabilitas Inklusi. Journal of Disability Studies, 3(2), 210-219.

Notohamidjojo. (1975). Demi Keadilan dan Kemanusiaan. BPK Gunung Mulia: Jakarta.
Republik Indonesia. (1945). Undang-Undang Dasar Negara Republik Indonesia Tahun 1945

Republik Indonesia. (2011). Undang-Undang Nomor 19 Tahun 2011 tentang Konvensi Hak-Hak Penyandang Disabilitas. Lembaran Negara Republik Indonesia Tahun 2011 Nomor 107.

Republik Indonesia. (2016). Undang-Undang Nomor 8 Tahun 2016 tentang Penyandang Disabilitas. Lembaran Republik Indonesia Tahun 2016 Nomor 69. Lembaran Negara. Tambahan Lembaran Negara Republik Indonesia Nomor 5871.

Soeprapto, E., et al. (2012). Hak Asasi Manusia Kelompok Rentan Dan Mekanisme Perlindungannya, Vulnerable Groups: Kajian dan Mekanisme Perlindungannya . Yogyakarta: Pusham UII.

Stein, M. A., \& Lord, J. E. (2010). Monitoring the Convention on the Rights of Persons with Disabilities: Innovations, Lost Opportunities, and Future Potential. Hum. Rts. Q., 32(1), 689-697.

United Nations. (2014). The Convention on the Rights of Persons with Disabilities: Training Guide Professional Training Series No. 19. United Nations Publication. 